\title{
The first description of the nymphal stages of
} Hoplopleura longula (Psocodea: Anoplura: Hoplopleuridae) from the harvest mouse Micromys minutus (Rodentia: Muridae)

\author{
Paulina Kozina ${ }^{\ddagger}$, Joanna N. Izdebska ${ }^{\ddagger}$, Rafał Kowalczyk $§$ \\ ‡ University of Gdansk, Faculty of Biology, Gdansk, Poland \\ $\S$ Mammal Research Institute Polish Academy of Sciences, Bialowieza, Poland
}

\section{Corresponding author: Paulina Kozina (paulina.kozina@ug.edu.pl)}

Academic editor: Vincent Smith

Received: 29 Jan 2021 | Accepted: 29 Mar 2021 | Published: 19 Apr 2021

Citation: Kozina P, Izdebska JN, Kowalczyk R (2021) The first description of the nymphal stages of Hoplopleura longula (Psocodea: Anoplura: Hoplopleuridae) from the harvest mouse Micromys minutus (Rodentia: Muridae). Biodiversity Data Journal 9: e63747. https://doi.org/10.3897/BDJ.9.e63747

\begin{abstract}
Background

Despite the widespread belief that an extensive body of knowledge exists for the sucking lice (Anoplura), some of their common, Eurasian or even cosmopolitan species still lack complete taxonomic descriptions, especially those for their nymphal stages. This applies especially to the most common rodent parasites: the lice of the genus Hoplopleura. In Europe, only two of the five most common Hoplopleura species have full taxonomic characteristics with a description of the nymphal stages. This study enriches the current state of knowledge for another species, Hoplopleura longula and presents the first description of its nymphal stages.

The study includes five rare louse specimens (two nymphs I, one nymph II, two nymphs III) of $H$. longula collected from 63 Eurasian harvest mice Micromys minutus. The collected lice were fixed and preserved in $70 \%$ ethyl alcohol solution and then placed in polyvinyllactophenol to form total preparations.
\end{abstract}




\section{New information}

Only two of the five species found in Eurasia $(H$. acanthopus, $H$. affinis, $H$. captiosa, $H$. edentula and $H$. longula) have been given full taxonomic descriptions, including immature stages. This paper presents a description of the nymphal stages of $H$. longula (described for the first time).

\section{Keywords}

mammals, parasite, rodents, sucking lice, taxonomy

\section{Introduction}

Sucking lice (Psocodea: Anoplura) are obligatory, permanent ectoparasites of mammals. Lice complete their entire lifecycle on their host and it includes: egg, three nymphal stages (nymph I, nymph II, nymph III) and an adult stage (imago). Some past research on this group has focused on their relationship with humans (e.g. Buxton 1941, Müller 1949, Piotrowski 1961, Fisher and Morton 1970, Downs et al. 1999, Roux and Raoult 1999, Levot 2000, Robinson et al. 2003, Izdebska 2014, Izdebska et al. 2018) or livestock (Piotrowski 1998, Mey 2003) and their potential for disease transmission (e.g. Piotrowski and Wegner 1976, Fagir et al. 2014). In comparision, there have been relatively few studies examining the sucking lice of wild fauna. As such, only fragmentary knowledge exists about certain species.

Approximately $70 \%$ of Anoplura are associated with rodents (Rodentia), the most abundant group of mammals in terms of species (Durden and Musser 1994, Baker et al. 2002, Kim 2006). The family Hoplopleuridae (Psocodea: Anoplura) is the most speciose group parasitising the Rodentia. Amongst the family, most representatives are in the genus Hoplopleura, which contains 154 species distributed around the world. The following five are most widespread in Europe - four of them being common in Eurasia: $\mathrm{H}$. acanthopus (Burmeister, 1839), $H$. affinis (Burmeister, 1839), H. edentula and H. longula Neumann, 1909 and one is probably cosmopolitan: H. captiosa Johnson, 1960 (Durden and Musser 1994).

Numerous publications concerning the ectoparasites of European fauna mention the presence of lice on rodents and insectivores (e.g. Krištofik 1999, Izdebska and Fryderyk 2010, Krčmar and Trilar 2017); however, concise taxonomic work concerning the genus Hoplopleura are scarce (Kim 1966, Johnson 1972, Weaver and Barton 2008) and the nymphal stages have been rarely described (Cook and Beer 1959, Johnson 1960, Kim 1966, Wegner 1966a). Of the species found in Eurasia, only two have been given full taxonomic descriptions, including their immature stages. This paper presents the first characterisation of the nymphal stages of Hoplopleura longula. 


\section{Materials and methods}

Five louse specimens were included in this study (two nymphs I, one nymph II and two nymphs III). These were isolated from four (out of 63 examined individuals) Eurasian harvest mice Micromys minutus (Pallas, 1771), obtained from the Scientific Collection of the Mammal Research Institute Polish Academy of Sciences in Białowieża (Table 1). The hosts originated from the area of the Białowieża National Park and the material was collected in the period 1949-1972. The specimens found were deposited in the Collection of Extant Invertebrates, University of Gdańsk, Department of Invertebrate Zoology and Parasitology, Gdańsk, Poland, UGDIZP (Table 1) (Zhang 2018).

Table 1.

Host specimens examined, louse life stages found and their location, with data on depositing in the Museum collections.

\begin{tabular}{|c|c|c|c|c|}
\hline $\begin{array}{l}\text { Host } \\
\text { number }\end{array}$ & $\begin{array}{l}\text { Host data (sex, collecting } \\
\text { date, museum number) }\end{array}$ & $\begin{array}{l}\text { Collected } \\
\text { parasites }\end{array}$ & $\begin{array}{l}\text { Parasites localisation on the } \\
\text { host body }\end{array}$ & Museum specimens numbers \\
\hline 1 & $\begin{array}{l}\text { male, 15.07.1950, } \\
\text { Bialowieza National Park }\end{array}$ & eggs & dorsal: left side of the body & - \\
\hline 2 & $\begin{array}{l}\text { male, 21.06.1949, } \\
\text { Bialowieza National Park }\end{array}$ & eggs & dorsal: left side of the body & - \\
\hline 3 & $\begin{array}{l}\text { male, 01.08.1949, } \\
\text { Bialowieza National Park }\end{array}$ & eggs & dorsal: tail area & - \\
\hline 4 & $\begin{array}{l}\text { male, 26.08.1949, } \\
\text { Bialowieza National Park }\end{array}$ & eggs & dorsal: right side of the body & - \\
\hline 5 & $\begin{array}{l}\text { male, 08.09.1949, } \\
\text { Bialowieza National Park }\end{array}$ & eggs & ventral: right side of the body & - \\
\hline 6 & $\begin{array}{l}\text { male, 06.11.1949, } \\
\text { Bialowieza National Park }\end{array}$ & eggs & ventral: left side of the body & - \\
\hline 7 & $\begin{array}{l}\text { female, 07.01.1949, } \\
\text { Bialowieza National Park }\end{array}$ & 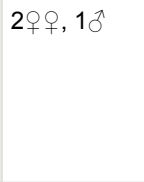 & $\begin{array}{l}\text { o dorsal: right side of the } \\
\text { body; ventral: right side of the } \\
\text { body } \\
\text { dorsal: right side of the body } \\
\text { (closer to the centre) }\end{array}$ & $\begin{array}{l}\text { UGDIZPMMmHHI1f, } \\
\text { UGDIZPMMmHHI2f, } \\
\text { UGDIZPMMmHHI1m, }\end{array}$ \\
\hline 8 & $\begin{array}{l}\text { male, 20.09.1949, } \\
\text { Bialowieza National Park }\end{array}$ & $\begin{array}{l}2 ㅇ, 1,1 \lesssim, 1 \\
\mathrm{~N} 1\end{array}$ & $\begin{array}{l}\text { + ventral: neck area, right side } \\
\text { of the body } \\
\text { dorsal: right side of the body } \\
\text { N1 dorsal: area between the } \\
\text { ears }\end{array}$ & $\begin{array}{l}\text { UGDIZPMMmHHI3f, } \\
\text { UGDIZPMMmHHI4f, } \\
\text { UGDIZPMMmHHI2m, } \\
\text { UGDIZPMMmHHI1N1 }\end{array}$ \\
\hline 9 & $\begin{array}{l}\text { male, 08.12.1949, } \\
\text { Bialowieza National Park }\end{array}$ & $\begin{array}{l}1 \text { Q , } 1 \mathrm{~N} 1,1 \\
\mathrm{~N} 2\end{array}$ & $\begin{array}{l}q \text { dorsal: left side of the body } \\
\text { and tail area } \\
N 1, N 2 \text { ventral: left side of the } \\
\text { body }\end{array}$ & $\begin{array}{l}\text { UGDIZPMMmHHI5f, } \\
\text { UGDIZPMMmHHI2N1, } \\
\text { UGDIZPMMmHHI1N2 }\end{array}$ \\
\hline 10 & $\begin{array}{l}\text { female, 07.10.1949, } \\
\text { Bialowieza National Park }\end{array}$ & $1 \delta, 2 \mathrm{~N} 3$ & $\begin{array}{l}\text { o dorsal: right side of the body } \\
\text { N3 dorsal: area between the } \\
\text { eyes, left side of the body }\end{array}$ & $\begin{array}{l}\text { UGDIZPMMmHHI3m, } \\
\text { UGDIZPMMmHHI1N3 } \\
\text { UGDIZPMMmHHI2N3 }\end{array}$ \\
\hline
\end{tabular}




\begin{tabular}{|l|l|l|l|l|}
\hline $\begin{array}{l}\text { Host } \\
\text { number }\end{array}$ & $\begin{array}{l}\text { Host data (sex, collecting } \\
\text { date, museum number) }\end{array}$ & $\begin{array}{l}\text { Collected } \\
\text { parasites }\end{array}$ & $\begin{array}{l}\text { Parasites localisation on the } \\
\text { host body }\end{array}$ & Museum specimens numbers \\
\hline 11 & $\begin{array}{l}\text { male, 25.08.1949, } \\
\text { Bialowieza National Park }\end{array}$ & eggs & $\begin{array}{l}\text { eggs dorsal: right side of the } \\
\text { body; ventral: right side of the } \\
\text { body }\end{array}$ & - \\
\hline
\end{tabular}

Lice were collected from dead rodent specimens by combing the fur with tweezers and the specimens were fixed and preserved in $70 \%$ ethyl alcohol. The specimens, intended for analysis of morphological traits, were immersed in polyvinyl-lactophenol to develop total preparations for light microscope examination (Kadulski and Izdebska 2006).

Topographic preferences were observed. The entire body surface area of the test hosts was analysed and all locations were marked; this allowed for a complete (intensive) analysis of the topography.

The names and abbreviations of individual setae or body parts are provided following Kim (1966) and Kim and Ludwig (1978) (Fig. 1).

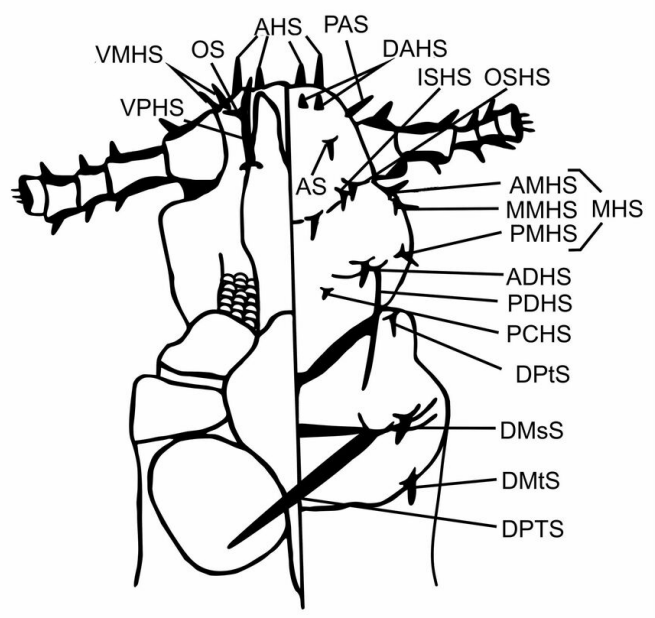

Figure 1. doi

Hoplopleura ventral (left) and dorsal (right) view of head and thorax.

Abbreviations of head and thorax:

- ADHS accessory dorsal head setae;

- AHS apical head setae;

- AS antennal setae;

- CS clypeal setae;

- DAHS dorsal anterior head setae;

- DMsS dorsal mesothoracic setae;

- DMtS dorsal metathoracic setae; 
- DPTS dorsal principal thoracic setae;

- DPtS dorsal prothoracic setae;

- ISHS inner sutural head setae;

- MHS marginal head setae;

- $\quad$ AMHS anterior marginal head setae;

- MMHS middle marginal head setae;

- $\quad$ PMHS posterior marginal head setae;

- OS oral setae;

- OSHS outer sutural head setae;

- PAS preantennal setae;

- PCHS posterior central head setae;

- $\quad$ PDHS posterior dorsal head setae;

- VMHS ventral marginal head setae;

- VPHS ventral principal head setae.

Abbreviations of abdomen:

- AnS anal setae;

- MAS major abdominal setae.

\section{Taxon treatment}

\section{Hoplopleura longula Neumann, 1909}

\section{Nomenclature}

Type host: Micromys minutus (Pallas, 1771)

Other hosts: Myodes glareolus Schreber, 1780 in Krištofik and Lysy (1992);

Microtus arvalis Pallas, 1778 and Sorex araneus Linnaeus, 1758 in Wegner (1966b)

\section{Materials}

a. scientificName: Hoplopleura longula Neumann, 1909; kingdom: Animalia; phylum: Arthropoda; class: Insecta; order: Psocodea; family: Hoplopleuridae; genus: Hoplopleura; continent: Europe; country: Poland; locality: area of the Bialowieza National Park; verbatimCoordinates: $52^{\circ} 45^{\prime} 23.3^{\prime \prime} \mathrm{N} 23^{\circ} 52^{\prime} 23.6^{\prime \prime} \mathrm{E}$; georeferenceProtocol: GPS; samplingProtocol: host Micromys minutus; eventDate: 20-09-1949; lifeStage: 1 nymph first instar; identifiedBy: Kozina P.; institutionCode: UGDIZPMMmHHI1N1

b. scientificName: Hoplopleura longula Neumann, 1909; kingdom: Animalia; phylum: Arthropoda; class: Insecta; order: Psocodea; family: Hoplopleuridae; genus: Hoplopleura; continent: Europe; country: Poland; locality: area of the Bialowieza National Park; verbatimCoordinates: $52^{\circ} 45^{\prime} 23.3^{\prime \prime} \mathrm{N} 23^{\circ} 52^{\prime} 23.6 " \mathrm{E}$; georeferenceProtocol: GPS; samplingProtocol: host Micromys minutus; eventDate: 08-12-1949; lifeStage: 1 nymph first instar and 1 nymph second instar; identifiedBy: Kozina P.; institutionCode: UGDIZPMMmHHI2N1, UGDIZPMMmHHI1N2 
c. ScientificName: Hoplopleura longula Neumann, 1909; kingdom: Animalia; phylum:

Arthropoda; class: Insecta; order: Psocodea; family: Hoplopleuridae; genus: Hoplopleura; continent: Europe; country: Poland; locality: area of the Bialowieza National Park; verbatimCoordinates: $52^{\circ} 45^{\prime} 23.3^{\prime \prime} \mathrm{N} 23^{\circ} 52^{\prime} 23.6 " \mathrm{E}$; georeferenceProtocol: GPS; samplingProtocol: host Micromys minutus; eventDate: 07-10-1949; lifeStage: 2 nymph third instar; identifiedBy: Kozina P.; institutionCode: UGDIZPMMmHHI1N3, UGDIZPMMmHHI2N3

\section{Description}

Nymph I (Figs 2, 3) . Legs large in proportion to the rest of the body, rapid growth with moulting to stage II; body length $0.53 \mathrm{~mm}$ (Table 2). Head. A poorly-marked line dividing the head and thorax. Ventral side: anterior part with the mouth rather depressed, not pronounced; convex scales around the mouth and in the site of the future gular plate; VMHS, OS and AHS present; VPHS very long, close to $75 \%$ of head length. Dorsal side: margins of the head shield poorly outlined; AHS, DAHS, PAS present; OSHS and ISHS present, very distant; ADHS and PDHS present, reaching half of the first thorax segment; a considerable number of convex, U-shaped scales. Thorax. Dorsal side: DPTS reaching anterior part of the thorax; DPtS, DMsS and DMtS shifted towards mid-portion of the body. Abdomen. Ovoid (directly after hatching: more elongated). MAS four in number; AnS present, two in number.

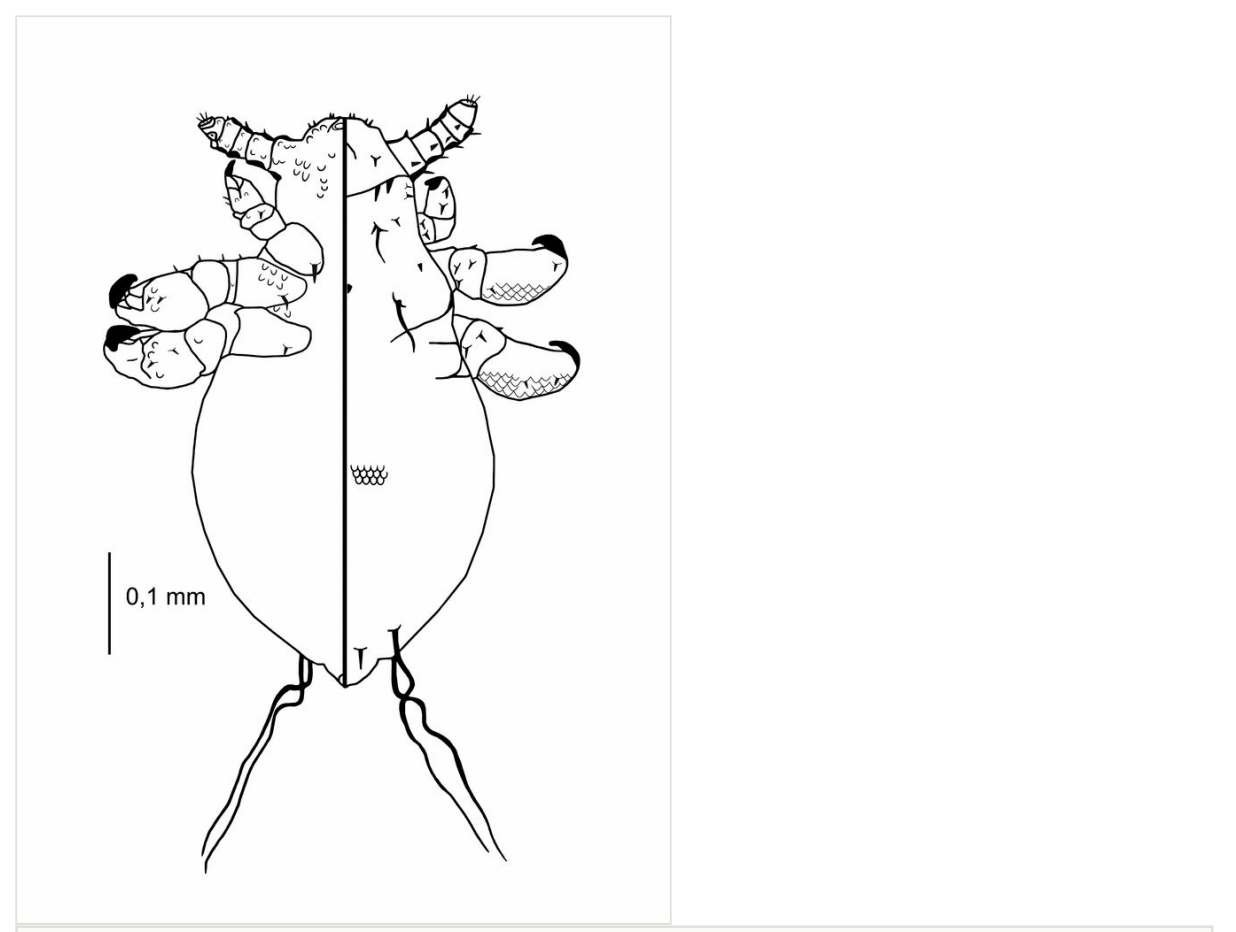

Figure 2. doi

Hoplopleura longula nymph I, ventral (left) and dorsal (right) view. 
Table 2.

Means and ranges of different immature stages of Hoplopleura longula [in mm].

\begin{tabular}{|l|l|l|l|}
\hline Features & $\begin{array}{l}\text { Nymph I } \\
{[\mathrm{N}=2]}\end{array}$ & $\begin{array}{l}\text { Nymph II } \\
{[\mathrm{N}=1]}\end{array}$ & $\begin{array}{l}\text { Nymph III } \\
{[\mathrm{N}=2]}\end{array}$ \\
\hline Head length & $0.12[0.12-0.12]$ & 0.18 & $0.14[0.13-0.14]$ \\
\hline Head width & $0.12[0.11-0.12]$ & 0.12 & $0.12[0.11-0.12]$ \\
\hline Thorax length & $0.09[0.09-0.10]$ & 0.10 & $0.18[0.12-0.23]$ \\
\hline Thorax width & $0.18[0.17-0.20]$ & 0.18 & $0.20[0.19-0.22]$ \\
\hline Abdomen length & $0.32[0.32-0.32]$ & 0.51 & $0.56[0.52-0.61]$ \\
\hline Abdomen width & $0.24[0.23-0.24]$ & 0.33 & $0.45[0.41-0.48]$ \\
\hline Whole body length & $0.53[0.53-0.54]$ & 0.78 & $0.87[0.87-0.88]$ \\
\hline
\end{tabular}

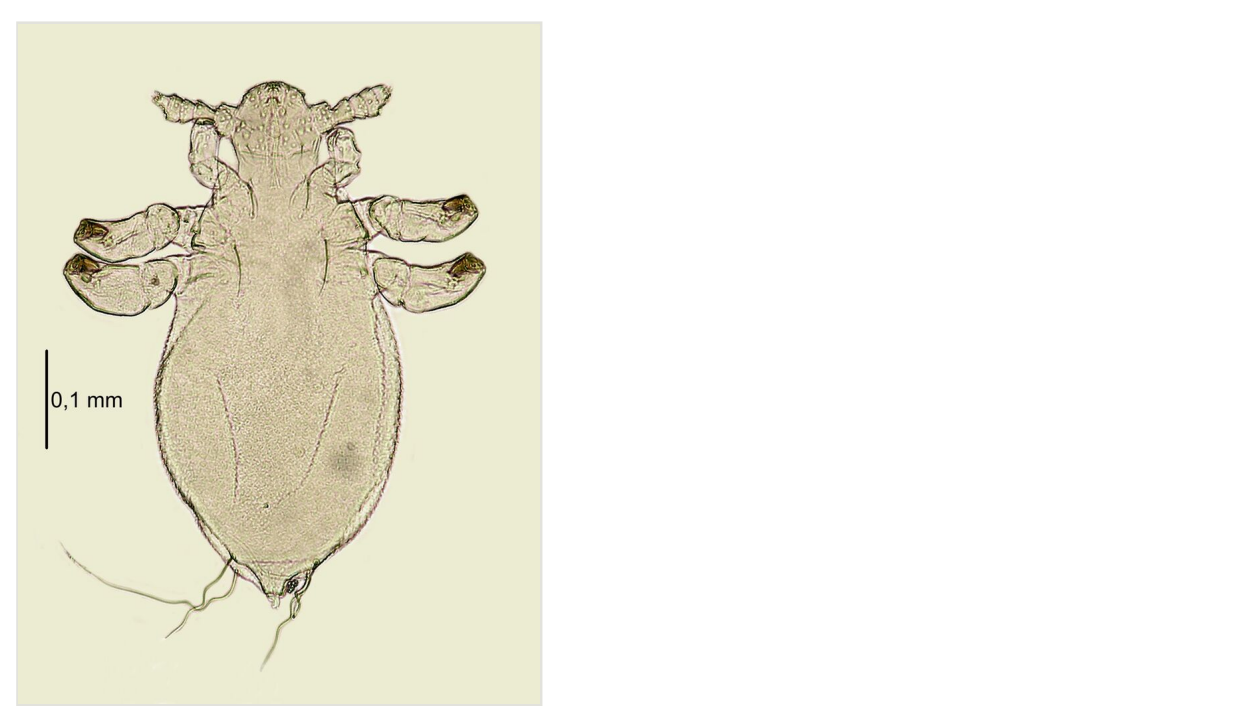

Figure 3. doi

Hoplopleura longula nymph I, dorsal view.

Nymph II (Figs 4, 5) . Body length: $0.78 \mathrm{~mm}$ (Table 2). Head. Wider than long; anterior part of the head shield square with smooth margins. Head well pronounced against the thorax (indentation visible at the contact point of both parts). Ventral side: large, concave scales around the mouth; head margins covered imbricately with scales (Ushaped); VMHS, OS and AHS present; VPHS constituting $50 \%$ of the head length. Dorsal side: AHS, DAHS and PAS present; ISHS and OSHS closely arranged; PCHS visible; ADHS and PDHS (reaching second segment of the abdomen) present; MHS minute. Thorax. Dorsal side: DPTS reaching beginning of the abdomen; pronounced border between the thorax, head and abdomen. Abdomen. Disproportionately large 
relative to the rest of the body, barrel-shaped, densely covered with U-shaped scales; traces of segmentation visible; MAS eight in number. After x-ray, structure of nymph III visible.

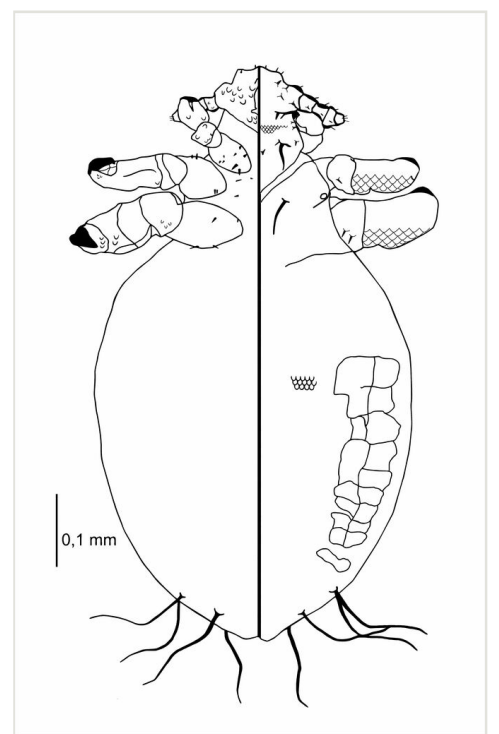

Figure 4. doi

Hoplopleura longula nymph II, ventral (left) and dorsal (right) view.

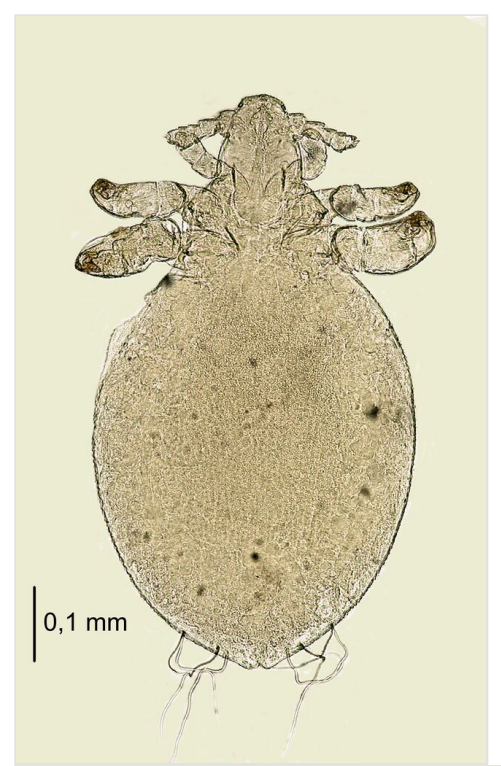

Figure 5. doi

Hoplopleura longula nymph II, dorsal view. 


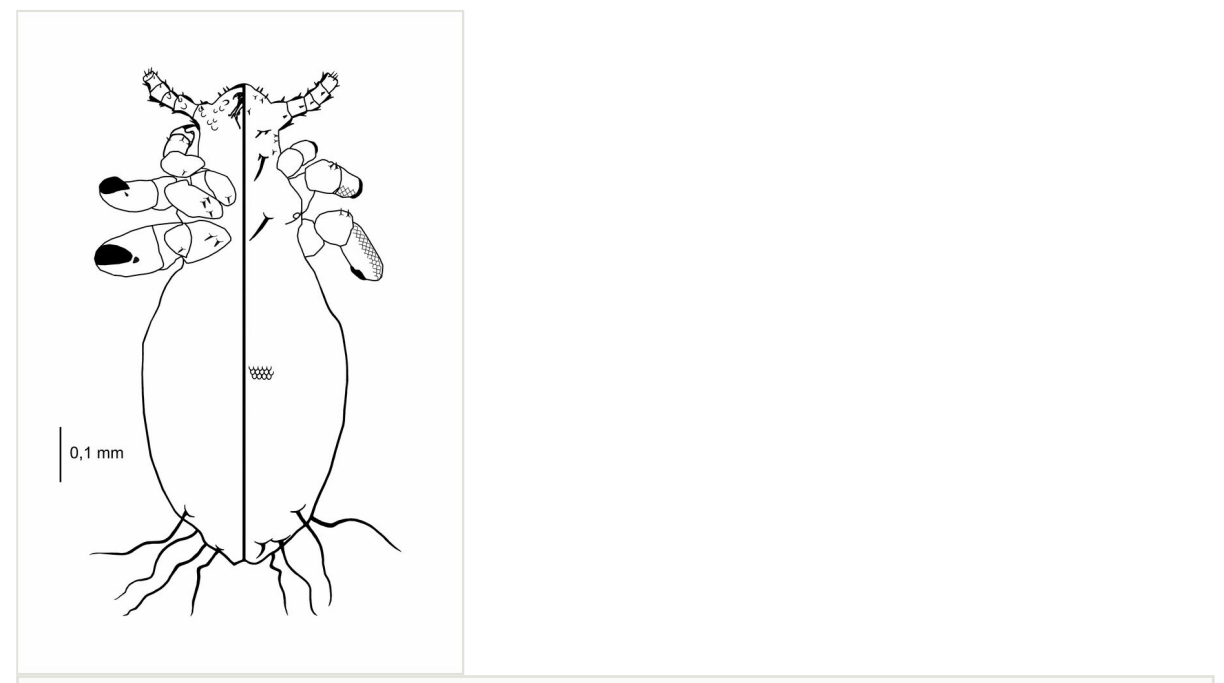

Figure 6. doi

Hoplopleura longula nymph III, ventral (left) and dorsal (right) view.

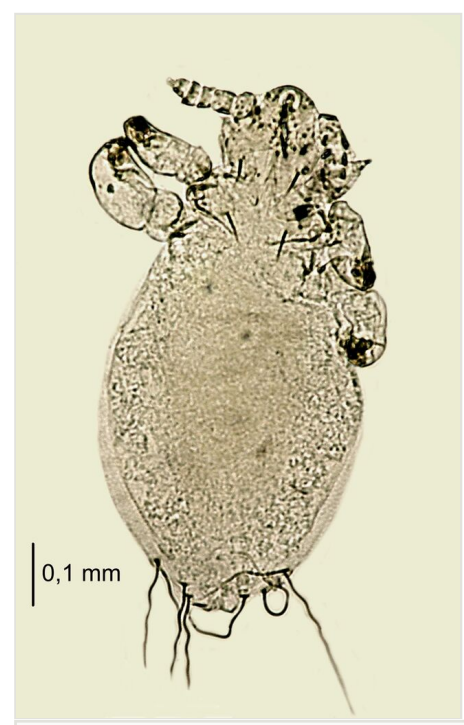

Figure 7. doi

Hoplopleura longula nymph III, dorsal view.

Nymph III (Figs 6,7) . Body of an adult, in the final stages of moulting, individual visible through the cuticle; body size sometimes smaller than in nymph II; body length: 0.87 $\mathrm{mm}$ (Table 2). Head. Wider than long. Ventral side: convex scales present, yet not as large as in nymph II; poorly visible on the head margins; VMHS, OS and AHS present; VPHS constitutes $50 \%$ of head length. Dorsal side: ISHS and OSHS present, similar length as in nymph II; PDHS long, reaching second segment of the abdomen, ADHS 
present. Thorax. Clearly visible borders between the thorax, head and abdomen. Dorsal side: DPTS reaching third segment of the thorax. Abdomen. Ovoid, elongated; MAS eight in number. After x-ray, sometimes adult individual visible (particular the plates and posterior part of the abdomen).

\section{Biology}

The lice demonstrated topographic preferences - a tendency for congregating along the sides of the host's body and on both sides of the head (between the ears and on the neck) (Fig. 8)(Table 1).

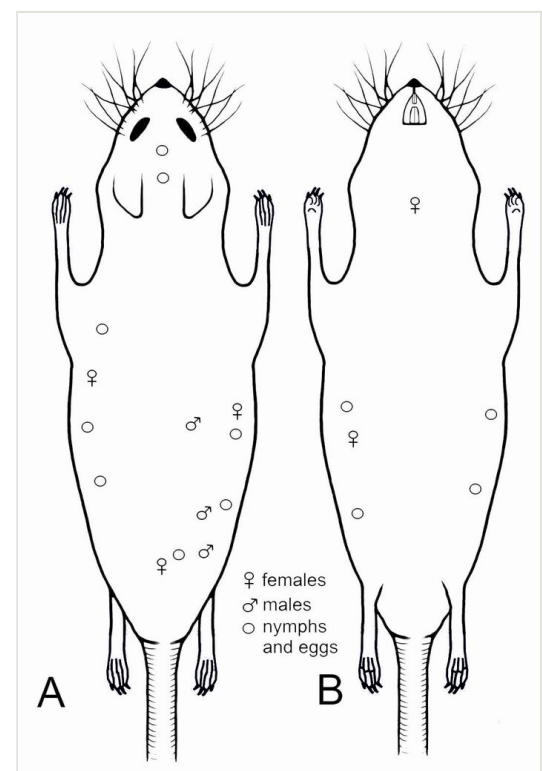

Figure 8. doi

Topographic preferences of all stages of Hoplopleura longula on host's body: A - dorsal and B - ventral view.

\section{Discussion}

In the present study, only $\mathrm{H}$. longula was found amongst the lice. Despite the fact that there are also other species parasitising $M$. minutus, for example, of the genus Polyplax given in literature (Durden and Musser 1994), they were not found on the studied rodents.

The harvest mouse $M$. minutus is considered to be the main host of $H$. longula; it has not been recorded in any other hosts to date (Wegner 1966a, Krištofik and Lysy 1992).

Individual nymphs of $H$. longula are easily identifiable. Nymph I possessed four major abdominal setae and an elongated, ovoid abdomen. Nymph II possessed eight MAS and a barrel-shaped abdomen. Like nymph II, nymph III possessed eight MAS; however, its 
abdomen is elongated and ovoid. In addition, like nymph I, the body of the adult individual can be seen inside the nymph.

Regarding the location of the lice on the host, no comparative data are available in previous studies regarding the $H$. longula- $M$. minutus relationship. Despite this, similarities can be found with the distribution of $H$. acanthopus on Microtus arvalis (Dubinin 1953): in both cases, the lice were found on the head, the posterior part of the abdomen and on both sides of the host body; however, $H$. longula appeared to have a wider distribution on the sides and the dorsum on its rodent hosts. Similarly to $H$. affinis in Apodemus agrarius (Dubinin 1953), $H$. longula was also found on the dorsal portion of the head and on the nape of the animal. In both of the previous studies, Dubinin did not observe lice on the ventral portion of the head; this was also confirmed in the present study.

Current research indicates that $H$. longula is a rare species associated with only one, also rare host, $M$. minutus. This is the first description of all three nymphal stages of $H$. longula. This characteristic will support other researchers working on lice to make positive identifications which will benefit future research examining host-parasite associations.

\section{References}

- $\quad$ Baker SC, Whiting M, Johnson KP, Murrel A (2002) Phylogeny of the lice (Insecta, Phthiraptera) inferred from small subunit rRNA. Zoologica Scripta 32: 407-414.

https://doi.org/10.1046/j.1463-6409.2003.00120.x

- $\quad$ Buxton PA (1941) On the occurence of the crab-louse (Phthirus pubis; Anoplura) in the hair of the head. Parasitology 33: 217-218. https://doi.org/10.1017/S0031182000024306

- $\quad$ Cook EF, Beer JR (1959) The immature stages of the genus Hoplopleura (Anoplura: Hoplopleuridae) in North America, with description of two new species. Journal of Parasitology 45: 405-416. https://doi.org/10.2307/3274391

- Downs AM, Stafford KA, Coles GC (1999) Head lice: Prevalence in Schoolchildren and insecticide resistance. Parasitology Today 15: 1-4. https://doi.org/10.1016/S01694758(98)01361-1

- Dubinin V (1953) Parasite fauna of rodents and its changes in the delta of Volga. Parazitologicheskij Sbornik 15: 252-301.

- Durden LA, Musser GG (1994) The mammalian hosts of the sucking lice (Anoplura) of the world: a host-parasite list. Bulletin of the Society for Vector Ecology 19: 130-168.

- $\quad$ Fagir DM, Ueckermann EA, Horak IG, Bennett NA, Lutermann H (2014) The Namaqua rock mouse (Micaelamys namaquensis) as a potential reservoir and host of arthropods vectors of diseases of medical and veterinary importance in South Africa. Parasites \& Vectors 7: 366. https://doi.org/10.1186/1756-3305-7-366

- $\quad$ Fisher RI, Morton RS (1970) Phthirus pubis infestation. The British Journal of Veneral Diseases 46: 326-329. https://doi.org/10.1136/sti.46.4.326

- Izdebska JN, Fryderyk S (2010) New data of sucking lice (Phthiraptera: Anoplura) of rodents (Rodentia: Muridae, Cricetidae) in the northern Poland. In: Buczek A, Błaszak C (Eds) Arthropods. Ecological and patological aspects of parasite - host relationship. Akapit, Lublin. URL: http://www.kleszcze.pl/wp-content/uploads/2018/02/Monografia2010.pdf 
- $\quad$ Izdebska JN (2014) Wszy. Poznaj i pokonaj problem. [Lice. Explore and overcome the problem]. Wydawnictwo Naukowe PWN, Warszawa, 72 pp.

URL: https://pokonajwszy.pwn.pl/

- $\quad$ Izdebska JN, Kozina P, Cierocka K, Mierzyński Ł (2018) Human lice Pediculus humanus and pediculosis in the past and present - occurrence, diagnostics and controlling. In: Buczek A, Błaszak C (Eds) Arthropods. At the beginning of the new Century. Koliber, Lublin.

- Johnson PT (1960) The Anoplura of African rodents and insectivores. Technical Bulletin 1211: 23-28. https://doi.org/10.22004/ag.econ.170730

- Johnson PT (1972) Some Anoplura from Oriental region. A study of Hoplopleura pacifica Ewing and Allies. Journal of Medical Entomology 9: 219-227. https://doi.org/ 10.1093/imedent/9.3.219

- $\quad$ Kadulski S, Izdebska JN (2006) Methods used in studies of parasitic arthropods in mammals. In: Buczek A, Błaszak C (Eds) Arthropods. Epidemiological importance. Koliber, Lublin. URL: http://www.kleszcze.pl/wp-content/uploads/2018/02/ Monografia-2006.pdf

- Kim KC (1966) A new species of Hoplopleura from Thailand, with notes and description of nymphal stages of Hoplopleura captiosa Johnson (Anoplura). Parasitology 56: 603-612. https://doi.org/10.1017/S0031182000071614

- Kim KC, Ludwig HW (1978) The family classification of the Anoplura. Systematic Entomology 3: 249-284. https://doi.org/10.1111/j.1365-3113.1978.tb00120.x

- $\quad \operatorname{Kim~KC~(2006)~Blood~sucking~lice~(Anoplura)~of~small~mammals:~True~parasites.~In:~}$ Morand S, Krasnov BR, Poulin R (Eds) Micromammals and microparasites from evolutionary to management. Springer Verlag, Tokyo. https://doi.org/10.1007/ 978-4-431-36025-4_9

- $\quad$ Krčmar S, Trilar T (2017) The blood sucking lice (Phthiraptera: Anoplura) of Croatia: review and new data. Turkish Journal of Zoology 41: 329-334. https://doi.org/10.3906/ zoo-1510-46

- Krištofik J, Lysy J (1992) Seasonal dynamics of sucking lice (Anoplura) in small mammals (Insectivora, Rodentia) in the natural foci of infections in South West Slovakia. Biologia 47: 605-617.

- Krištofik J (1999) Sucking lice (Phthiraptera) from Mongolian mammals. Biologia 54: 143-149.

- Levot G (2000) Resistance and control of lice on humans and production animals. International Journal of Parasitology 30: 291-297. https://doi.org/10.1016/ s0020-7519(99)00203-9

- Mey E (2003) On the development of animal louse systematics (Insecta, Phthiraptera) up to the present day. Rudolfstädter Naturhistorische Schriften 11: 115-134.

- Müller F (1949) Das Zahlenverhältnis der Geschlechter in Zuchtpopulationen der Kleiderlaus (Pediculus corporis de Geer, Anoplura). Zeitschrift für Parasitenkunde 14: 285-299.

- $\quad$ Piotrowski F (1961) Morphogenesis of the pathways of the sexual system of human lice Pediculus humanus L. (Anoplura). Acta Zoologica Cracoviensis 5: 583-660.

- $\quad$ Piotrowski F, Wegner Z (1976) Division: Insects (Insecta) cd. Order: Sucking lice (Anoplura). In: Żółtkowski Z (Ed.) Arachnoentomologia lekarska. Państwowy Zakład Wydawnictw Lekarskich, Warszawa. 
- $\quad$ Piotrowski F (1998) News about biology and combating Anoplura. Wiadomości Parazytologiczne 44: 37-40.

- Robinson D, Leo N, Prociv P, Baker SC (2003) Potencial role of head lice, Pediculus humanus capitis, as vector of Rickettsia prowazekii. Parasitology Research 90: 209-211. https://doi.org/10.1007/s00436-003-0842-5

- Roux V, Raoult D (1999) Body Lice as Tools of Diagnosis and Surveillance of Reemerging Diseases. Journal of Clinical Microbiology 37: 569-599. https://doi.org/ 10.1128/jcm.37.3.596-599.1999

- Weaver HJ, Barton PS (2008) A new species of sucking louse (Phthiraptera: Anoplura) from Australia, and a key to the Australian species of Hoplopleura. Zootaxa 1679: 55-62. https://doi.org/10.11646/zootaxa.1679.1.3

- Wegner Z (1966a) The immature stages of the louse Hoplopleura captiosa Johnson syn. Hoplopleura musculi Wegner. Bulletin of the Institute of Maritime and Tropical Medicine 17: 29-34.

- Wegner Z (1966b) Wszy. Anoplura. In: Jaczewski T (Ed.) Katalog Fauny Polski. Państwowe Wydawnictwo Naukowe, Warszawa, 3 pp.

- Zhang ZQ (2018) Repositories for mite and tick specimens: acronyms and their nomenclature. Systematic and Applied Acarology 23: 2432-2447. https://doi.org/ $\underline{10.11158 / \text { saa.23.12.12 }}$ 